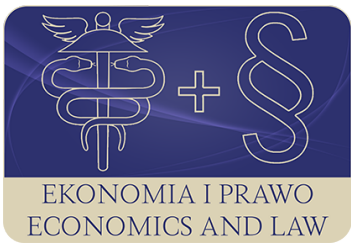

EKONOMIA I PRAWO. ECONOMICS AND LAW

Volume 18, Issue 4, December 2019

p-ISSN 1898-2255, e-ISSN 2392-1625

www.economicsandlaw.pl

EKONOMIA I PRAWO
ECONOMICS AND LAW

ORIGINAL ARTICLE

received 30.03.2019; revised 12.12.2019; accepted 31.12.2019

Citation: Lulek, A. (2019). Information on environmental protection and annual reports of oil companies. Ekonomia i Prawo. Economics and Law, 18(4): 475-486.

doi:10.12775/EiP.2019.031.

\title{
Information on environmental protection and annual reports of oil companies
}

\author{
ADAM LULEK \\ University of Szczecin, Institute of Economic and Finance, Department of Accounting, \\ ul. Cukrowa 8, 71-004 Szczecin, Poland \\ ๑adam.lulek@usz.edu.pl \\ (D) orcid.org/0000-0001-6709-1291
}

\begin{abstract}
Motivation: The stakeholders of annual reports want to obtain as much information of sufficient quality as possible in order to take appropriate decisions. These reports include information on a company structure and should reflect its true image. They also contain environmental information concerning the way a company affects, develops and manages the natural environment. This information is of great importance in oil companies which operational activity is connected with significant environmental risk. Therefore, they should thoroughly inform stakeholders of their impact on the environment. In practice, however, environmental information is presented differently. The thesis can be formulated that data presented in financial statements does not satisfy all information needs of stakeholders.

Aim: The purpose of the article is to prove that: (1) information on the natural environment published in the reports of oil companies is of great significance to stakeholders, (2) the amount and quality of environmental information included in the annual reports of oil companies are insufficient for stakeholders, (3) annual reports of oil companies differ considerably in terms of their informative content.

Results: Defining the disadvantages of current financial statements regarding ecological information and assessment of the presentation of environmental information in the annual reports of selected oil companies.
\end{abstract}

Keywords: information; ecological information; financial statements; oil companies JEL: Q01; Q56; Q5; Q41 


\section{Introduction}

The term environmental information is not explicitly defined in the literature. According to the author, it is information on the management, protection, use and development of the environment in a broad sense. Such information should be provided by all companies which even indirectly influence the environment (Mohd Said et al., 2014). The topic of presenting environmental information in reports is very important for their stakeholders - local communities, stock investors, households, etc.

Although financial reporting provides a lot of useful information expressed in money, it does not provide data presenting a complete picture of an enterprise on the market. Nowadays, still many reports do not include at all or include insufficient information concerning the natural environment as not all companies are interested in publishing such information. It is a wrong attitude from the point of view of reporting which should provide a wide range of information to all interested users.

The thesis can be formulated that data presented in financial statements does not satisfy all information needs of stakeholders, thus such features as (Samelak, 2004, p. 165):

- formal correctness,

- compatibility of financial data with the data included in financial statements,

- data completeness,

- information timeliness,

- reliability of the presented information,

- comparability,

- relevance,

- information clarity.

\section{Literature review}

An annual report should include information about corporate social responsibility and the natural environment a company has an influence on (Yuan \& $\mathrm{He}$, 2015). In the case of oil companies this is very important information because it concerns operational activity (Sadowska, 2018). The purpose of the article is to prove that (1) information on the natural environment published in the reports of oil companies is of great significance to stakeholders, (2) the amount and quality of environmental information included in the annual reports of oil companies are insufficient for stakeholders, (3) annual reports of oil companies differ considerably in terms of their informative content.

It is worth emphasising that one of the main legal sources which regulate access to environmental information is Aarhus Convention (UNECE, 1998). Its objective is to provide society with the possibilities of obtaining information on matters concerning the environment. This act imposes an obligation to collect environmental information on public authorities and ensures that individu- 
als have access to it (Balicka, 2014, p. 138). It means that oil companies should inform of especially the impact on the natural environment. Due to the large interference in the environment, sceptics do not see the future for fuel companies, especially when it comes to oil extraction (Boudet et al., 2014, pp. 57-67).

The problem of environmental information in financial statements has been raised in various studies for many years. One of them is Study on environmental reporting by companies published by European Commission. The report indicates dysfunctions related to including this type of information in reporting. It also distinguishes various types of environmental information and recommends appropriate actions for companies. A similar report was prepared by the Ministry of the Environment of Japan. Other articles also pay attention to types of environmental information, their certification and presentation in reports (Deegan \& Rankin, 1997; Pavaloaia, 2015).

Environmental risk is characteristic of many production enterprises. It concerns in particular oil, energy and chemical companies. Their activities are connected with landfill, hazards during operational activity and other fortuitous events which a management board is not always able to predict. For the above reasons, an annual activity report should include information about the natural environment a company has an influence on. In the case of oil companies this is very important information as it may indirectly influence a given company's share price. For example, a company generates contamination which gets to groundwater, thus a large area becomes contaminated.

The key to the selection of oil companies was market capitalization on the world's stock exchanges. Every year, the Financial Times publishes a list of companies with the largest market capitalization in the world. They are listed in the Financial Times Global 500. In May 2018, the largest oil companies in the world by market capitalization were as follows:

- Exxon Mobil (USA) - the largest oil and gas corporation in the world which was established in 1999 as a result of the merger of Exxon and Mobil. The corporation deals with searching for new deposits, exploration, extraction and refining;

- Royal Dutch Shell (UK) - a petrochemical company which main goal is to extract natural gas and crude oil. The company also deals with processing, distribution and sales;

- Chevron (USA) - an energy corporation which generates revenues from the oil, gas and geothermal industries as well as from exploration and production, refining, marketing, transport and sales of chemicals and power.

- Petro China (China) - the largest Chinese petrochemical company. It invests funds in refineries in Sudan, Australia and China. The company's shares significantly increased after the rise of natural gas prices for commercial use;

- Total (France) - its activities include the entire oil and gas chain, from crude oil and natural gas exploration and production to power generation, transportation, refining, petroleum product marketing, and international crude oil and product trading; 
- BP(UK) - a company which operates in over 70 countries around the world, including Poland. The company's goal is to produce and sell fuel and raw materials;

- China Petroleum \& Chemical Corp. (China) - a company that specializes in natural gas and crude oil extraction as well as their processing and distribution. The company is also a leader in the production and distribution of oil derivative products such as, e.g. polymers, synthetic fibres, synthetic rubber;

- Reliance Industries (India) - a company involved in activities connected with energy, petrochemicals, textiles, natural resources, retail, and telecommunications. The company is one of the most profitable companies in India;

- Petroleo Brasilieiro (Brazil) - a corporation dealing with crude oil and natural gas extraction, natural gas import and transportation as well as oil and gas processing. The corporation exploits many deposits mainly in the Gulf of Mexico, Nigeria, India, Turkey, Angola, Argentina, Bolivia and Venezuela.

- Statoil (Equinor) (Norway) - a company which operates in over 38 countries, including Poland. In the first quarter of 2018, the company changed its name from Statoil to Equinor what should indicate moving away from fossil fuels. Similarly, the company's petrol stations were rebranded and currently they operate under the name of Circle K.

The aforementioned oil companies present information concerning the natural environment in their annual reports. The examples of such information are presented in table 1.

After the thorough analysis of financial statements of the largest oil companies, the following collective conclusion can be drawn: oil companies put much emphasis on presenting environmental information in their financial statements. However, they do it in very different ways which depend on many factors.

\section{Methods}

When writing the article, the author used the methods of inductive and deductive reasoning as well as descriptive analysis of financial statements of the largest oil companies in the world in terms of capitalization. The author also used the method of comparative analysis. The research process involved the identification of a research problem, that is the problem of the insufficient quality and amount of environmental information described in the reports of oil companies. The next research stage was about commenting on the problem by analyzing environmental information included in financial statements of oil companies. On the basis of the above, conclusions were drawn. 


\section{Results}

Annual reports also differ in terms of their structure and volume. It is difficult to compare environmental information from various reports of oil companies. In each of them, data is located in completely different places and is difficult to find by a user. It is presented in table 2 . The annual reports of the largest oil companies in the world differ in terms of their structures and methods of presenting information, including information on the natural environment. The reasons behind that drawback may be as follows:

- the companies come from various countries where there are different legal regulations concerning the preparation and presentation of reporting data;

- international regulations and optional provisions are insufficient in order to standardize reports;

- the table of contents and informative content of reports depend heavily on people responsible for their preparation.

\section{Conclusion}

After the analysis of annual reports in terms of the presentation of information on the natural environment, one may try to formulate the following conclusions:

- annual reports have various tables of contents and due to that are not comparable;

- the content of reports is not standardized therefore, it is difficult to find necessary information on the natural environment;

- due to the various content of reports, it is difficult to compare descriptive data of a few reports;

- annual reports lack figures concerning expenses on the protection of the natural environment;

- reports are too extensive.

Table 3 contains the assessment of the presentation of information on the natural environment in the annual reports of the companies included in the study. As it was mentioned before, the presentation method varies between companies, what is reflected in the grades given in particular categories.

In order to change this situation, international panels of experts should propose greater harmonization and standardization of reports, whereas oil companies could put more emphasis on:

- standardizing the tables of content, providing their framework plan where one of chapters will be about environmental protection;

- implementing 'an obligation' to provide figures concerning the natural environment, including quality data;

- putting emphasis on publishing integrated reports;

- not duplicating the same information, therefore, the annual report would be more concise. 
The indicated solutions complement the conclusions from the literature on this topic. Many publications indicate the distinction of specific types of environmental information, which the author agrees to. Furthermore, the suggested solutions could considerably enhance the knowledge of the stakeholders of annual reports in terms of environmental protection. Their implementation could make obtaining information by stakeholders quicker and easier. Moreover, they could receive more information about company activities in terms of environmental protection. Consequently, it would contribute to taking more accurate decisions by stakeholders. Recipients of the reports could make better decisions regarding the purchase of shares in a given company. Creditors could assess whether a company is worth borrowing cash. For local communities, information on environmental protection is associated with buying products from company. Depending on the type of stakeholder, each has a completely different purpose of obtaining information about the environment and making various decisions based on it. This is a very broad topic that can be addressed in the next article.

\section{References}

Balicka, A. (2014). Informacje środowiskowe w raportach rocznych przedsiębiorstw branży motoryzacyjnej. Zeszyty Naukowe Uniwersytetu Szczecinskiego. Finanse, Rynki Finansowe, Ubezpieczenia, 69.

Boudet, H., Clarke, C., Bugden, D., Maibach, E., Roser-Renouf C., \& Leiserowitz, A. (2014). 'Fracking' controversy and communication: using national survey data to understand public perceptions of hydraulic fracturing. Energy Policy, 65. doi:10.1016/j.enpol.2013.10.017.

BP. (2016). Annual report and form 20-F2016. Retrieved 30.06.2019 from https:// www.bp.com.

Chevron. (2016). Annual report 2016. Retrieved 30.06.2019 from https://www. chevron.com.

Deegan, C., \& Rankin, M. (1997). The materiality of environmental information to users of annual reports. Accounting, Auditing \& Accountability Journal, 10(4). doi:10.1108/09513579710367485.

Exxon Mobil. (2016). Corporate citizenship report 2016. Retrieved 30.06.2019 from https://corporate.exxonmobil.com.

Mohd Said, R., Sulaiman, M., \& Nazli Nik Ahmad, N. (2014). Environmental information usefulness to stakeholders: empirical evidence from Malaysia. Social Responsibility Journal, 10(2). doi:10.1108/srj-10-2012-0131.

Pavaloaia, L. (2015). Environmental information reporting and certification in annual reports. Procedia Economics and Finance, 20. doi:10.1016/ S2212-5671(15)00102-1.

Petro China. (2016). Petro China Company Limited annual report 2016. Retrieved 30.06.2019 from http://www.petrochina.com. 
Petrobras. (2016). Form 20-F annual report 2016. Retrieved 30.06.2019 from http://www.investidorpetrobras.com.br.

Reliance Industries. (2017). Integrated annual report 2016-17. Retrieved 30.06.2019 from http://www.ril.com.

Royal Dutch Shell. (2016). Annual report and form 20-F 2016. Retrieved 30.06.2019 from https://reports.shell.com.

Sadowska, B. (2018). Raportowanie informacji o społecznej odpowiedzialności sektora komunalnego. Studia i Prace Kolegium Zarządzania i Finansów SGH, 163.

Samelak, J. (2004). Determinanty sprawozdawczości finansowej przedsiębiorstw oraz kierunki jej dalszego rozwoju. Poznań: AE.

Sinopec. (2016). Annual report and accounts 2016. Retrieved 30.06.2019 from http://www.sinopec.com.

Statoil. (2017). Annual report and form 20-F 2017. Retrieved 30.06.2019 from https://www.equinor.com.

Total. (2016). Form 20-F: 2016 edition. Retrieved 30.06.2019 from https:// www.total.com.

UNECE. (1998). Convention on access to information, public participation in decision-making and access to justice in environmental matters. Retrieved 30.06.2019 from http://www.unece.org.

Yuan, T., \& He, Z. (2015). The market factors of influence environmental information disclosure and market reactions. In S. Yingying, C. Guiran, \& L. Zhen (Eds.), Proceedings of the International Conference on Logistics, Engineering, Management and Computer Science. Atlantis Press. doi:10.2991/ lemcs-15.2015.285.

\section{Acknowledgements}

Author contributions: author has given an approval to the final version of the article.

Funding: this research was undertaken as part of the RID project and was fully funded by a grant (RID/WZIEU/2019/1/081).

Note: the results of this study were presented at 10th International Conference on Applied Economics Contemporary Issues in Economy (June 27-28, 2019, Torun, Poland). 


\section{Appendix}

Table 1.

\section{Corporate social responsibility and environmental protection of oil companies on the basis of financial statements}

Company Environmental information in financial statements

- we must also work to reduce the environmental impact of global development and do our part in mitigating the risks of climate change. We recognize that these risks are serious and warrant thoughtful action, requiring large-scale, economic, broad-based solutions implemented around the world;

Exxon

Mobil

(2016)

- ExxonMobil is committed to conducting business in a manner that is compatible with both the environmental and economic needs of the communities in which we operate, while protecting the safety, security, and health of our employees, contractors, and the public;

- strong environmental management is crucial for our business and for society;

- we engage local communities and other stakeholders to better understand local perspectives on the environment.

- our success in business depends on our ability to meet a range of environmental and social challenges;

- we aim to minimise the environmental impact of new projects and existing operations and we engage with local comRoyal munities and non-governmental organisations to understand

Dutch

Shell

(2016)

and respond to their concerns;

- we seek to comply with environmental regulations, to continually improve our performance, and to prepare to respond to future challenges and opportunities.

2016 health, environment and safety performance set or matched record lows in many of our core safety metrics;

- the company is subject to various international, federal, state and local environmental, health and safety laws, regulations and market-based programs;

- Chevron estimated its worldwide environmental spending Chevron in 2016 at approximately 2.1 billion USD for its consolidated (2016) companies;

- the company is subject to loss contingencies pursuant to laws, regulations, private claims and legal proceedings related to environmental matters that are subject to legal settlements or that in the future may require the company to take action to correct or ameliorate the effects on the environment of prior release of chemicals or petroleum substances, including MTBE, by the company or other parties.
Information on corporate social responsibility, including environmental protection in financial statements: conclusions

Exxon Mobil significantly contributes to corporate social responsibility. The corporation repeatedly emphasises that it supports environmental protection as well as local communities and shareholders.

Royal Dutch Shell treats environmental protection as a very important aspect for the company's development due to the company's activities which affect it. The company assures that it does everything to protect the environment by observing international regulations. Moreover, the corporation spares a lot of funds on environmental protection, thus these costs are high.

The company probably tries to observe the principles of corporate social responsibility however, it is not explicitly stated. When reading the company's annual report, the user may have the impression that the most important information is only financial data. The company should at every step, also in its annual report, emphasise its commitment to corporate social responsibility. 
Company Environmental information in financial statements

- a number of international, domestic and regional agreements restricting greenhouse gas emission have been signed and become effective:

Petro

China

(2016)

- the company actively performed its social responsibilities and devoted to becoming an excellent corporate citizen of the world, and adhered to the principle of "environmental priorities, safety first, quality-oriented, people-oriented’, and strictly abided by the Environmental Protection Law and other relevant laws and regulations to prevent and control pollution, enhance ecological protection and maintain social safety.

- for many years, the Group has been developing a normative framework related to occupational health and safety, security, societal commitment and the environment;

Total

(2016)

- total implements an active policy of avoiding, reducing, managing and monitoring the environmental footprint of its operations.

- we aim to create long-term value for our shareholders, partners and society by helping to meet growing energy demand in a safe and responsible way;

- safety is one of our values and our number one priority. Our stated aim is to have no accidents, no harm to people and no BP (2016) damage to the environment;

- BP-operated businesses are responsible for identifying and managing operating risks and bringing together people with the right skills and competencies to address them;

- we work to avoid, minimize and mitigate environmental impacts from our activities.

- in 2016, we earmarked a total of RMB 6.584 billion to promote social, educational, medical and healthcare development in the areas where we have operations;

Sinopec

- during the reporting period, Sinopec Corp. was in full compliance with domestic and overseas laws and regulations as well as the Articles of Association of the Company and operates in line with all legal requirements and its corporate governance has been further improved.

- Reliance works towards bridging the developmental gap between rural ,Bharat' and urban India by improving rural livelihood, addressing poverty, hunger and malnutrition.

Reliance Industries (2017)
- during FY 2016-17, Reliance contributed 674 crore towards Corporate Social Responsibility (CSR);

- the company seeks to transform lives by leveraging technology and innovation. The endeavour is to provide sustainable solutions for the marginalised and underprivileged communities across India.
Information on corporate social responsibility, including environmental protection in financial statements: conclusions

The company indicates that it observes the principles of corporate social responsibility, but only on its website and in additional reports, but not in the annual report.

It should be noted that corporate social responsibility is one of the most important aspects of the company. This issue is extensively elaborated in the company's annual report which is in the section on corporate social responsibility.

BP may be considered as one of the most popular oil companies among individual clients worldwide. The company enjoys the confidence of the public opinion thanks to its activities for the natural environment and social activities, what was presented in the annual report.

In the letter to shareholders and friends, the company states that it actively fulfilled social duties and participated in campaigns supporting environmental protection. On the company's website, one can find a lot of information proving that corporate social responsibility is of great significance to the company.

Reliance Industries has probably the greatest impact on the natural environment among the largest oil companies in the world mentioned in this study. In the annual report, the company describes how it protects the nature. Corporate social responsibility is one of the company's main pillars. The company's attitude in this matter is highly commendable. 
Company Environmental information in financial statements

- the protection of human health and the environment is one of our primary concerns and is essential to our success as an integrated energy company;

- we have a Health, Safety and Environmental (HSE) Committee (Comitê de Segurança, Meio Ambiente e Saúde) composed of three members of our board of directors who are responsible for assisting our board;

Petrobras

(2016)

- our efforts to address health, safety and environmental concerns and ensure compliance with environmental regulations (which in 2016 totalled an investment of 5.88 billion BRL, or 1.68 billion USD) involve the management of environmental costs related to production and operations, pollution control equipment and systems, projects to rehabilitate degraded areas, safety procedures and initiatives for emergency prevention and control, health and safety programs.

- the risks associated with Statoil's activities are affected by the difficult geographies, climate zones and environmentally sensitive regions in which Statoil operates;

- the transition towards a lower carbon economy is underway. During 2017, Statoil embedded our response to climate change into our sharpened business strategy. Statoil aims

Statoil

(2017) to develop a high value, lower carbon portfolio that will be robust to future fluctuations in energy prices and potentially higher carbon costs;

- Statoil is committed to using resources efficiently and responsible management of waste, emissions to air and impacts on ecosystems. This reduces the impact on the local environment and can also save costs.
Information on corporate social responsibility, including environmental protection in financial statements: conclusions

Similarly to other oil companies, Petrobras implements corporate social responsibility. The data included in the report shows that the company has spent a lot of funds on environmental protection.

The company strongly emphasises that the activities it conducts are connected with risk concerning safety, health and the natural environment. The company tries to reduce this risk by observing international regulations.

Source: Own preparation.

Table 2.

Analysis of the report structures in terms of the content of information on the natural environment

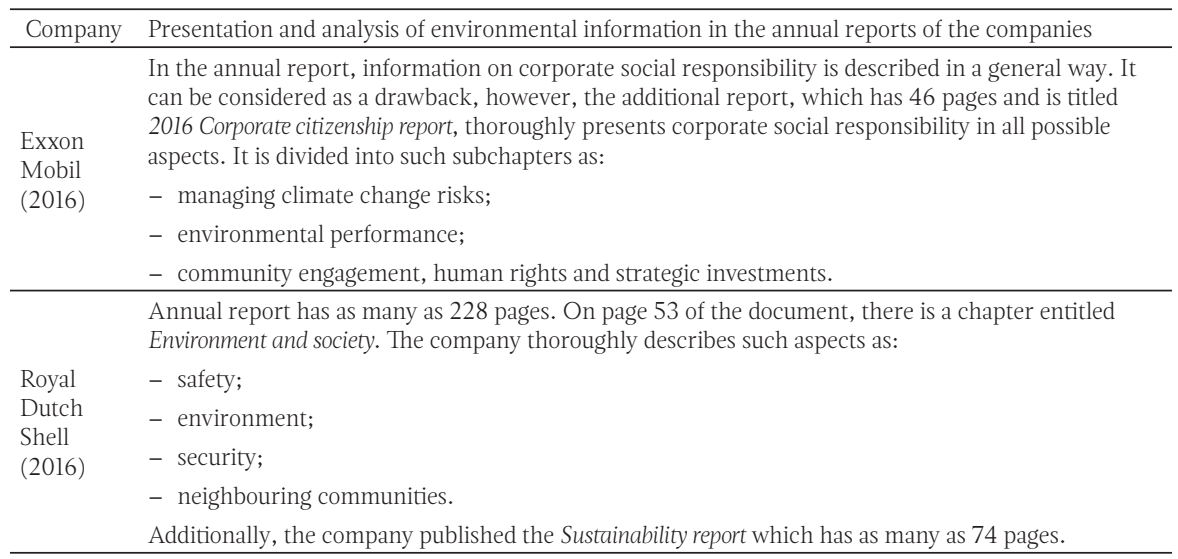




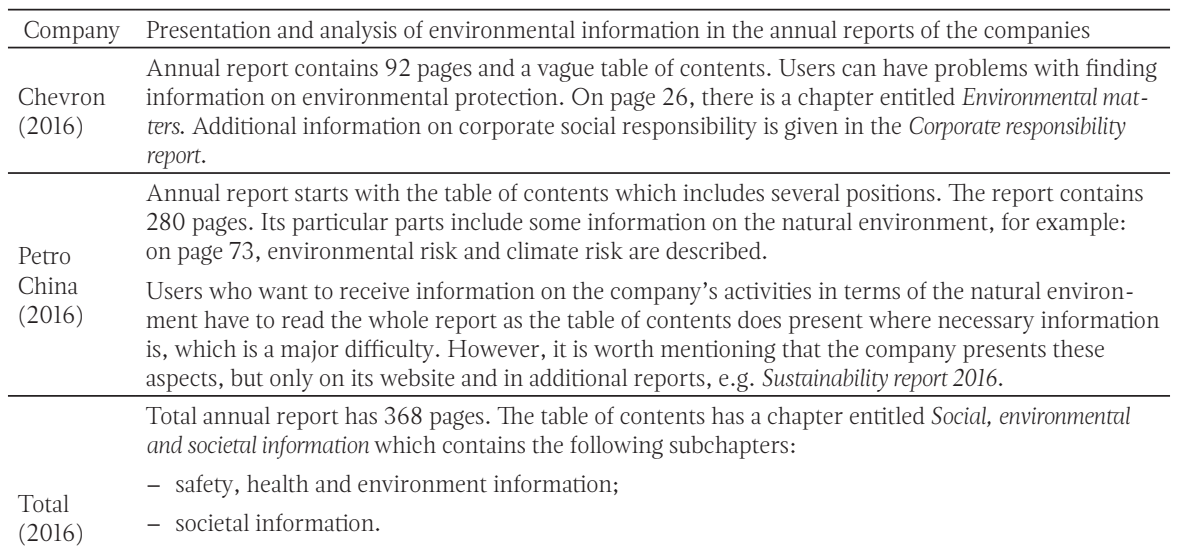

The presentation of information concerning corporate social responsibility in this report can be deemed almost ideal. It is exceptionally detailed and extensive. Moreover, apart from descriptive information, there are also tables and graphs.

The report contains 294 pages. It starts with a fairly detailed table of contents. For the purpose of the article, the most significant chapter is Sustainability which is mainly divided into the following subchapters:

- safety;

- climate change;

BP (2016) - local environmental impacts;

- ethical conduct.

Annual report can be positively evaluated in terms of information on environmental protection it contains. Highlighting key aspects in the table of contents makes the report users find necessary information quickly.

The annual report contains 213 pages. There is a table of contents at the beginning of the document which lists several chapters, including Corporate Governance. The table of contents does not enable

Sinopec finding information on corporate social responsibility. The company presents it briefly in, among

(2016) other things, the letter to shareholders, the cash flow description (expenditure on the environment), the corporate governance section. As in the case of other companies, additional reports dealing with the protection of the natural environment are available on the company's website.

The annual report of this enterprise contains 460 pages. The table of contents includes, for example, such positions as:

- people and innovation;

Reliance

- report on corporate social responsibility;

Industries - business responsibility report;

(2017) - independent reasonable assurance on sustainability disclosures;

- corporate governance report.

Although the report is very extensive, environmental information can be easily found. A considerable part of the report involves the description of the company's impact on local communities, health, education, ecology, the environment and sustainable development.

The report has 405 pages and is divided into chapters. There are such chapters as:

Petrobras - health, safety and environmental initiatives;

(2016) - corporate governance.

This extensive report does not include a lot of information on environmental protection. One can find additional reports which present corporate social responsibility in detail on the company's website. 


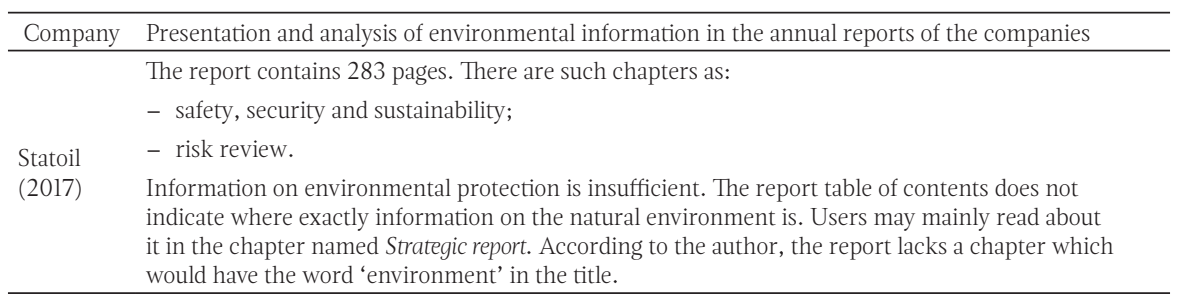

Source: Own preparation.

Table 3.

The evaluation of the presentation of information on the natural environment in annual reports of the selected oil companies

\begin{tabular}{lccc}
\hline \multicolumn{1}{c}{ Company } & Information comprehensiveness & Information relevance & Table of contents \\
\hline Exxon Mobil (2016) & sufficient & good & very good \\
Royal Dutch Shell (2016) & very good & very good & good \\
Chevron (2016) & insufficient & insufficient & insufficient \\
Petro China (2016) & insufficient & very good & insufficient \\
Total (2016) & very good & very good & very good \\
BP (2016) & good & sufficient & insufficient \\
Sinopec (2016) & insufficient & very good & very good \\
Reliance Industries (2017) & very good & sufficient & good \\
Petrobras (2016) & sufficient & good & sufficient \\
Statoil (2017) & sufficient & &
\end{tabular}

Notes:

Table 3 shows the evaluation of the presentation of information on the natural environment in annual reports of the selected oil companies on the basis of the analysis of companies' annual reports. The evaluation was carried out on the basis of three criteria: information comprehensiveness, information relevance as well as table of contents. The grading scale is as follows (from the highest to the lowest grade): very good, good, sufficient, insufficient.

Source: Own preparation. 